Vol 1 No 22020 Desember 2020

Jurnal AlphaEuclidEdu

\title{
TINGKAT KEPUASAN MAHASISWA TERHADAP LAYANAN AKADEMIK
}

\author{
${ }^{1}$ Hamdani, ${ }^{2}$ Asep Nursangaji \\ 1,2 Pendidikan Matematika FKIP Universitas Tanjungpura Pontianak \\ Email: hamdani.mikraj@fkip.untan.ac.id
}

\begin{abstract}
Nowadays, there are several LPTK in West Kalimantan that have mathematics education courses apart from FKIP UNTAN. This is a challenge for FKIP UNTAN to become the main choice for prospective students. So, it is very important for the FKIP UNTAN mathematics education department to provide quality academic services to students so that they feel satisfied. One of the student satisfaction assessments index in academic services in the Mathematics Education Department of FKIP UNTAN is academic guidance and course implementation. This study will examine how high the level of student satisfaction with academic services in the Mathematics education Department FKIP UNTAN. Furthermore, it will be known what service items should be improved and developed in an effort to increase student satisfaction. The method used is descriptive method with a survey form involving students in 3rd, 5th, and 7th semester. The instrument used is a satisfaction questionnaire. The level of student satisfaction with academic guidance services is $2 \%$ of students are not satisfied, $6 \%$ of students are not satisfied, 30\% of students are satisfied, 32\% of students are quite satisfied, and 30\% of students are very satisfied. Then for the level of student satisfaction with the lecture process as much as $2 \%$ of students were not satisfied, $5 \%$ of students were not satisfied, $27 \%$ of students were satisfied, 36\% of students were quite satisfied, and 30\% of students were very satisfied.

Keywords: Satisfaction; Academic Services; Academic Guidance; The Lecture Process.
\end{abstract}

\section{Pendahuluan}

Perguruan Tinggi sebagai salah satu lembaga pendidikan pada dasarnya adalah organisasi jasa, yakni memberikan layanan pendidikan pada masyarakat. Sebagai organisasi jasa, Perguruan Tinggi dituntut untuk memberikan pelayanan yang terbaik kepada pelanggan, khususnya kepada mahasiswa karena akan mempengaruhi kualitas lulusan yang dihasilkan. Fakultas Keguruan dan Ilmu Pendidikan (FKIP) Untan sebagai salah satu organisasi layanan publik, tentu juga memiliki tantangan yang sama dengan FKIP/lembaga Kependidikan Perguruan Tinggi lainnya. FKIP mengalami kondisi persaingan yang sama sehingga harus memikirkan strategi peningkatan kualitas pelayanan yang memberi kepuasan kepada mahasiswanya.Sejauh ini, Prodi Pendidikan Matematika FKIP UNTAN telah berusaha semaksimal mungkin untuk memberikan layanan akademik kepada mahasiswa sebagai konsumennya. Karena pelayanan akademik yang berkualitas akan menciptakan lulusan/mahasiswa yang berkualitas sehingga mampu bersaing di era globailsasi/ era revolusi industri 4.0. Layanan akademik tersebut, seperti: perkuliahan, kurikulum, bimbngan/konsultasi akademik, praktikum, bimbingan tugas akhir, dan lainlain (Tampubolon, 2001). Salah satu indeks penilaian kepuasan mahasiswa dalam layanan akademik di Prodi Pendidikan Matematika FKIP Untan adalah bimbingan akademik dan pelaksanaan perkuliahan.Dalam kehidupan perkuliahan, setiap mahasiswa pasti diberikan dosen pembimbing akademik yang berfungsi sebagai penunjuk arah dan advisor 
Vol 1 No 22020 Desember 2020

Jurnal AlphaEuclidEdu

mahasiswa dalam mengambil mata kuliah pada tiap semester berjalan. Setelah mendapat arahan dan petunjuk tentang mata kuliah yang akan diambil, tentunya mahasiswa akan menjalani proses perkuliahan pada tiap mata kuliah. Dari kedua indeks tersebut tentunya harus diperhatikan aspek kemudahan dan kenyamanan interaksi antara mahasiswa sebagai pelanggan dan dosen sebagai penyedia layanan.

\section{Metode Penelitian}

\section{Pendekatan Penelitian}

Penelitian ini menggunakan Pendekatan kuantitatif dengan metode deskriptif. penggunaan metode deskriptif bertujuan untuk menggambarkan secara jelas tentang kepuasan mahasiswa terhadap kualitas layanan akademik pada prodi pendidikaan matematika FKIP Untan tahun akademik 2019/2020.

Bentuk penelitian yang digunakan adalah survey studies

Waktu dan Tempat Penelitian

Penelitian ini berlokasi di Prodi Pendidikan Matematika FKIP UNTAN, yang dilakukan pada bulan Mei - Oktober 2020

\section{Populasi dan Sampel}

Populasi dalam penelitian ini adalah mahasiswa Prodi Pendidikan Matematika FKIP Untan semester 3, 5, dan 7 untuk data kepuasan layanan bimbingan akademik dan perkuliahan. Pembatasan tersebut dimaksudkan untuk menjaring mahasiswa yang telah benar-benar merasakan pelayanan pendidikan, sehingga mereka bisa menilai tingkat kepuasan serta tingkat urgensi dari pelayanan tersebut.

Untuk pengambilan sampel survei, peneliti menggunakan probability sampling, yaitu teknik pengambilan sampel yang memberikan peluang yang sama bagi setiap unsur (anggota) populasi untuk dipilih menjadi anggota sampel, dan teknik yang dipilih adalah proportionate random sampling, yaitu pengambilan anggota sampel dilakukan dengan memperhatikan proporsi yang ada dalam populasi itu.

\section{Analisis Data}

Analisis data menggunakan analisis deskriptif dengan mencari rata-rata tingkat kepuasan mahasiswa untuk masing-masing dimensi dan secara umum kemudian dibuat interval. Rentang tersebut akan digunakan sebagai dasar kriteria tingkat kepuasan mahasiswa.

\section{Hasil dan Pembahasan}

\section{Tingkat Kepuasan Mahasiswa Terhadap layanan Bimbingan Akademik}

Kepuasan mahasiswa terhadap layanan bimbingan akademik diukur dengan 13 pernyataan dengan 5 tingkat kepuasan. 5 tingkat kepuasan yang digunakan adalah tidak puas, kurang puas, puas, cukup puas, dan sangat puas. Berdasarkan hasil analisis data kuisioner yang diisi oleh 150 mahasiswa sebagai responden, didapatkan data tingkat 
Vol 1 No 22020 Desember 2020

Jurnal AlphaEuclidEdu

kepuasan mahasiswa terhadap layanan bimbingan akademik yang ditunjukan dalam gambar 1 . 
Vol 1 No 22020 Desember 2020

Jurnal AlphaEuclidEdu

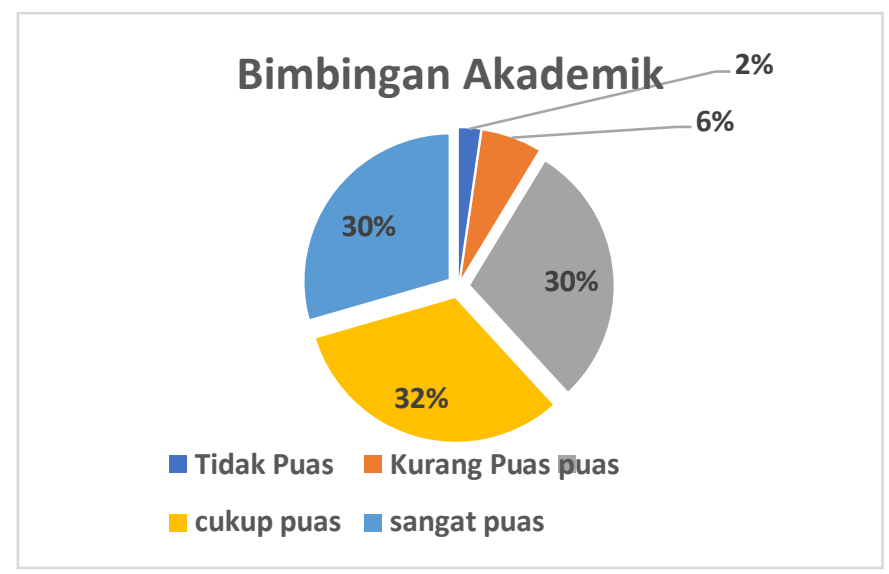

Gambar 1. Diagram tingkat kepuasan

mahasiswa terhadap layanan bimbingan

akademik.

Berdasarkan diagram di atas, dari 150 mahasiswa, sebanyak 3 mahasiswa merasa tidak puas, 9 mahasiswa merasa kurang puas, 45 mahasiswa merasa puas, 48 mahasiswa merasa cukup puas, dan 45 mahasiswa merasa sangat puas dengan layanan bimbingan akademik yang diberikan oleh para dosen yang bertupoksi sebagai dosen pembimbing akademik mahasiswa Program Studi Pendidikan Matematika Fakultas Keguruan dan Ilmu Pendidikan Universitas Tanjungpura.

Berdasarkan analisis data kuisioner yang dilakukan dengan menghitung sebaran skor di setiap distribusi frekuensi kemudian diinterpretasikan dengan kriteria persentase, dari 150 mahasiswa, sebanyak 2\% mahasiswa merasa tidak puas, 6\% mahasiswa merasa kurang puas, $30 \%$ mahasiswa merasa puas, 32\% mahasiswa merasa cukup puas, dan $30 \%$ mahasiswa merasa sangat puas dengan layanan bimbingan akademik yang diberikan oleh para dosen yang bertupoksi sebagai dosen pembimbing akademik mahasiswa Program Studi Pendidikan Matematika Fakultas Keguruan dan Ilmu Pendidikan Universitas Tanjungpura.

Secara umum semua indikator kepuasan dinilai sudah memuaskan dengan hasil kepuasan $92 \%$. Artinya pelayanan bimbingan akademik yang diberikan oleh para dosen yang bertupoksi sebagai dosen pembimbing akademik mahasiswa Program Studi Pendidikan Matematika Fakultas Keguruan dan Ilmu Pendidikan Universitas Tanjungpura sudah cukup baik. Hal ini menunjukkan bahwa para dosen pembimbing akademik masingmasing mahasiswa sudah berusaha sangat cukup optimal dalam menjalankan tugas pokok dan fungsinya sebagai pembimbing. Aspek - aspek yang membuat mahasiswa puas dengan layanan bimbingan akademik oleh dosen pembimbing akademik adalah ketersedian waktu 
Vol 1 No 22020 Desember 2020

Jurnal AlphaEuclidEdu

dan kemudahan untuk ditemui oleh para mahasiswa bimbingan ( Availability ). Pemahaman tentang layanan akademik dan administrasi akademik ( Understanding). Penguasaan sarana dan prasarana bimbingan akademik berupa SIAKAD UNTAN (Ability). Dan memberikan panduan serta solusi pada masalah yang dihadapi oleh para mahasiswa bimbingan.( Guiding and Problem Solving). Aspek - aspek tersebut merupakan hal yang penting untuk mewujudkan layanan bimbingan akademik yang prima, sesuai pendapat Parasuraman (Noermanjati,2010) yang menyatakan bahwa hal-hal yang dinginkan mahasiswa kepada dosen sebagai unit layanan akademik yaitu mengenai ketersediaan, keramahan, pemahaman dan interaksi dosen pembimbing akademik dengan mahasiswa bimbingannya.

Berdasarkan data di atas juga, Hasil kepuasan masih menunjukkan adanya kecenderungan ketidakpuasan aspek sebesar 8\%. Masih terdapat beberapa persen mahasiswa Program Studi Pendidikan Matematika Fakultas Keguruan dan Ilmu Pendidikan Universitas Tanjungpura yang merasa kurang puas bahkan tidak puas dengan layanan bimbingan akademik yang telah diberikan oleh dosen pembimbing akademik. Setelah dilakukan penelusuran lanjutan, hal yang membuat beberapa persen mahasiswa kurang puas bahkan tidak puas adalah ketidakakraban mahasiswa tersebut dengan DPAnya , kemudian juga ada yang tidak mendapatkan arahan atau gambaran mengenai masa depan mereka setelah lulus dari Program Studi Pendidikan Matematika Fakultas Keguruan dan Ilmu Pendidikan Universitas Tanjungpura. factor - factor yang menyebabkan hal tersebut yaitu kurangnya intensitas pertemuan mahasiswa tersebut dengan dosen pembimbing akademiknya, pertemuan hanya dilakukan sekali tiap semester dengan agenda laporan atau ada arahan mata kuliah atau bahkan hanya sekedar meminta tanda tangan LIRS saja. Factor lainnya adalah karakteristik mahasiswa yang tidak homogen, ada yang aktif, ada juga yang pasif.

Maka dari itu, hal - hal yang dapat dilakukan untuk meningkatkan kepuasan mahasiswa secara menyeluruh adalah dengan memperbanyak intensitas agenda bimbingan akademik. Baik itu agenda arahan mata kuliah hingga agenda controlling atau conseling. Kemudian dapat dilakukan kegiatan pembekalan karir bagi mahasiswa yang akan memasuki tahap akhir dari perkuliahan S1 Program Studi Pendidikan Matematika Fakultas Keguruan dan Ilmu Pendidikan Universitas Tanjungpura. Sehingga ada gambaran, arahan dan tujuan bagi para mahasiswa. Hal itu juga dapat meningkatkan motivasi untuk menyelesaikan proses tugas akhir mereka masing- masing.

Tingkat Kepuasan Mahasiswa Terhadap Layanan Proses Perkuliahan

Kepuasan mahasiswa terhadap layanan proses perkuliahan diukur dengan 15 pernyataan dengan 5 tingkat kepuasan. 5 tingkat kepuasan yang digunakan adalah tidak puas, kurang puas, puas, cukup puas, dan sangat puas. Berdasarkan hasil analisis data kuisioner yang diisi oleh 150 mahasiswa sebagai responden, didapatkan data tingkat 
Vol 1 No 22020 Desember 2020

Jurnal AlphaEuclidEdu

kepuasan mahasiswa terhadap layanan proses perkuliahan yang ditunjukkan di dalam gambar 2.

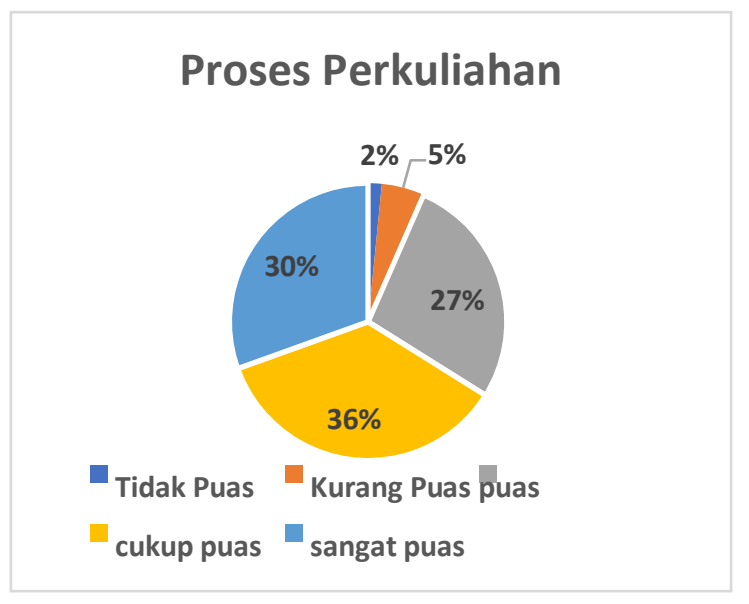

Gambar 2. Diagram tingkat kepuasan mahasiswa terhadap layanan proses perkuliahan.

Berdasarkan diagram di atas, dari 150 mahasiswa, sebanyak 3 mahasiswa merasa tidak puas, 8 mahasiswa merasa kurang puas, 41 mahasiswa merasa puas, 54 mahasiswa merasa cukup puas, dan 45 mahasiswa merasa sangat puas dengan layanan proses perkuliahan yang diberikan oleh para dosen yang bertupoksi sebagai dosen pengampu mata kuliah di Program Studi Pendidikan Matematika Fakultas Keguruan dan Ilmu Pendidikan Universitas Tanjungpura.

Berdasarkan analisis data kuisioner yang dilakukan dengan menghitung sebaran skor di setiap distribusi frekuensi kemudian diinterpretasikan dengan kriteria persentase, dari 150 mahasiswa, sebanyak $2 \%$ mahasiswa merasa tidak puas, $5 \%$ mahasiswa merasa kurang puas, $27 \%$ mahasiswa merasa puas, 36\% mahasiswa merasa cukup puas, dan 30\% mahasiswa merasa sangat puas dengan layanan proses perkuliahan yang diberikan oleh para dosen yang bertupoksi sebagai dosen pengampu mata kuliah Program Studi Pendidikan Matematika Fakultas Keguruan dan Ilmu Pendidikan Universitas Tanjungpura.

Secara umum semua indikator kepuasan dinilai sudah memuaskan dengan hasil kepuasan 93\%. Artinya pelayanan proses perkuliahan yang diberikan oleh para dosen yang bertupoksi sebagai dosen pengampu mata kuliah Program Studi Pendidikan Matematika Fakultas Keguruan dan Ilmu Pendidikan Universitas Tanjungpura sudah cukup baik. Hal ini menunjukkan bahwa para dosen pengampu mata kuliah sudah berusaha sangat cukup optimal dalam menjalankan tugas pokok dan fungsinya sebagai pengampu Aspek - aspek yang membuat mahasiswa puas dengan layanan proses perkuliahan oleh dosen pengampu mata kuliah adalah ketepatan waktu memulai dan mengakhiri perkuliahan ( Time Management ). Penguasaan materi mata kuliah yang diampu (Mastering ). Melakukan proses konfirmasi dan klarifikasi kepada mahasiswa pada materi dalam mata kuliah yang 
Vol 1 No 22020 Desember 2020

Jurnal AlphaEuclidEdu

diampu, memastikan kelas mahasiswa mengerti sebelum lanjut ke materi berikutnya.

Berdasarkan data di atas juga, Hasil kepuasan masih menunjukkan adanya kecenderungan ketidakpuasan aspek sebesar 7\%. Masih terdapat beberapa persen mahasiswa Program Studi Pendidikan Matematika Fakultas Keguruan dan Ilmu Pendidikan Universitas Tanjungpura yang merasa kurang puas bahkan tidak puas dengan layanan proses perkuliahan yang telah diberikan oleh dosen pengampu mata kuliah. Setelah dilakukan penelusuran lanjutan, hal yang membuat beberapa persen mahasiswa kurang puas bahkan tidak puas adalah ketidakpahaman mahasiswa terhadap penyampaian dosen pengampu mata kuliah, kemudian juga ada yang merasa bosan dengan gaya penyampaian dosen pengampu mata kuliah yang cenderung tidak menarik dan monoton. Dan yang terakhir adalah proses evaluasi dosen pengampu mata kuliah yang berujung dengan beragamnya nilai akhir mata kuliah yang diampu. factor - factor yang menyebabkan hal tersebut yaitu karakteristik mahasiswa yang tidak homogen, ada yang aktif, ada juga yang pasif., ada yang rajin, pasti ada juga yang kurang rajin, dan perbedaan daya tangkap yang dimiliki oleh kelas mahasiswa. Factor lainnya adalah dosen pengampu kurang mengamati kondisi kelas dan kurang memanfaatkan fasilitas untuk membuat suasana pembelajaran menjadi efektif secara menyeluruh.

Maka dari itu, hal - hal yang dapat dilakukan untuk meningkatkan kepuasan mahasiswa secara menyeluruh adalah dengan mengkondisikan kelas dan memetakan kemampuan kelas mahasiswa sehingga dapat dilakukan tindak lanjut untuk mencapai pemahaman kelas yang merata. Selanjutnya adalah dosen pengampu mata kuliah harus sudah memulai memanfaatkan berbagai jenis teknologi dan fasilitas yang dapat membangkitkan focus dan keefektifan proses perkuliahan mata kuliah tersebut.

\section{Kesimpulan dan Saran}

\section{Kesimpulan}

Tingkat kepuasan mahasiswa terhadap layanan bimbingan akademik adalah 2\% mahasiswa merasa tidak puas, 6\% mahasiswa merasa kurang puas, 30\% mahasiswa merasa puas, 32\% mahasiswa merasa cukup puas, dan 30\% mahasiswa merasa sangat puas. Kemudian untuk tingkat kepuasan mahasiswa terhadap proses perkuliahan adalah sebanyak $2 \%$ mahasiswa merasa tidak puas, 5\% mahasiswa merasa kurang puas, 27\% mahasiswa merasa puas, $36 \%$ mahasiswa merasa cukup puas, dan $30 \%$ mahasiswa merasa sangat puas

Hal- hal yang harus diperbaiki untuk meningkatkan kepuasan mahasiswa terhadap layanan akademik secara menyeluruh adalah dengan memperbanyak intensitas agenda bimbingan akademik. kemudian melakukan kegiatan pembekalan karir bagi mahasiswa yang akan memasuki tahap akhir dari perkuliahan, mengkondisikan kelas dan memetakan kemampuan kelas mahasiswa sehingga dapat dilakukan tindak lanjut untuk mencapai pemahaman kelas yang merata, dan memulai memanfaatkan berbagai jenis teknologi dan fasilitas yang dapat membangkitkan focus dan keefektifan proses perkuliahan mata kuliah tersebut. 
Vol 1 No 22020 Desember 2020

Jurnal AlphaEuclidEdu

\section{Saran}

Perlu dilakukan tindak lanjut dari hasil penelitian ini sehingga dapat meningkatkan mutu layanan dan mutu sumber daya manusa di Program Studi Pendidikan Matematika Fakultas Keguruan dan Ilmu Pendidikan Universitas Tanjungpura.

\section{Referensi}

Buchari Alma. 2009. Pemasaran Jasa Pendidikan yang Fokus Pada Mutu, dalam Buchari Alma dan Ratih Hurriyati (ed.), ManajemenCorporate \& Strategi Pemasaran Jasa Pendidikan. Bandung: Alfabeta.

Elliot, K..; Shin, D. 1999. Assessing student satisfaction: an approach to help in the development of marketing strategy for a university. Marketing Management Association.

Jurkowitsch, Silke, et.al. 2006, A Student Satisfaction Model For Austrian Higher Education Providers Considering Aspects Of Marketing Communications, Special Edition On Consumer Satisfaction - Global Perspective, pp. 9-23

Kotler, Philip. 1997. Manajemen Pemasaran, Analisis, Perencanaan, Implementasi dan Control Jilid I. Edisi-9 Jakarta: PT Prenhallindo

Mahmud, Marzuki. 2012. Manajemen Mutu Perguruan Tinggi. Jakarta: Rajawali Press. Supranto, J.2006. Pengukuran Tingkat Kepuasan Pelanggan. Jakarta: Rieneka Cipta Tampubolon, Daulat P. 2001. Perguruan Tinggi Bermutu. Jakarta: PT. Gramedia Pustaka Utama Tjiptono, Fandy. 1997. Strategi Pemasaran. Yogyakarta: Andi Offset.

Yamif, Zuliam. 2001. Manajemen Kualitas Produk. Yogyakarta: Ekonisia

Zeithaml, V.A. dan Bitner, M.J. 2000. Services Marketing: Integrating Customer Focus Across the Firm. (United States of America: Irwin McGraw-Hill 